\title{
Attitudes of Syrian and Iraqi Refugees in Germany toward Jews ${ }^{1}$
}

Antisemitism is on the rise again in twenty-first century Germany. Jews feel increasingly threatened. ${ }^{2}$ Antisemitism is not limited to certain individual social groups. It is found on both the left and right wings of the political spectrum, as well as in the mainstream. Immigrants are also said to hold antisemitic sentiments. However, antisemitism is a problem in Germany, even without taking immigration or the large numbers of newly arrived refugees into account. As a relatively large proportion of these refugees comes from countries where hatred of Jews is a part of official government propaganda and education, the questions arise whether the increased levels of immigration are also leading to an increased risk of antisemitism, and if so, what can be done to counter this development.

Refugee attitudes are also relevant regarding the question of integration. What "integration" actually means and how far the German public and the refugees will move toward one another remains to be seen. When interacting at school, in the workplace, in public, in the media, or in the political sphere, immigrant populations seeking integration will not only encounter the immediate challenges of learning the language and obtaining professional qualifications; over the long term, attitudes toward democracy, gender roles, religion, minorities, and because of Germany's history, toward Jews and Israel in particular, will play a significant role in the process of integration. A major review of integration practices of refugees in seven European countries stresses the "importance of introducing asylum seekers to core European values, including gender

1 An earlier and substantially longer version of this essay was published in German in December 2017 in G. Jikeli, Einstellungen von Geflüchteten aus Syrien und dem Irak zu Integration, Identität, Juden und Shoah: Forschungsbericht Dezember 2017 (Berlin: American Jewish Committee, 2017), https://docplayer.org/68777670-Einstellungen-von-gefluechteten-aus-syrien-unddem-irak-zu-integration-identitaet-juden-und-shoah-forschungsbericht-dezember-2017.html. The research was supported by the Bennett Fund and the Meyer Fund.

2 A series of interviews conducted by the University of Bielefeld at the request of the German Parliament's Independent Circle of Experts on Antisemitism in May and June 2016 showed that $37 \%$ of Jews interviewed were worried about possible assaults and $58 \%$ avoided certain places or parts of the city due to security concerns. Seventy percent wear no visible Jewish symbols out of fear; see A. Zick et al., Jüdische Perspektiven auf Antisemitismus in Deutschland. Ein Studienbericht für den Expertenrat Antisemitismus (Bielefeld: Institut für interdisziplinäre Konfliktund Gewaltforschung, Universität Bielefeld, 2017), https://uni-bielefeld.de/ikg/daten/JuPe_Be richt_April2017.pdf, 4.

Ә OpenAccess. (C) 2021 Armin Lange, Kerstin Mayerhofer, Dina Porat, Lawrence H. Schiffmann, published by De Gruyter. (cc) BY-NC-ND This work is licensed under the Creative Commons Attribution-NonCommercialNoDerivatives 4.0 International License. https://doi.org/10.1515/9783110671964-015 
equality, tolerance regarding sexual orientation and the role of religion in secular Western societies from the very beginning of the integration process," in addition to providing a safe haven, access to the labor market, and housing. ${ }^{3}$ There has already been broad public debate on three issues, about which refugees are thought to hold anti-democratic positions: Islamism, sexism, and antisemitism. These debates have been based mostly on anecdotal evidence, and they often do not take into account the diversity of different groups of refugees and the fact that many of them have become victims of Islamism, sexism, religious intolerance, and racism themselves, both from the indigenous population and from other migrants. However, such attitudes-Islamism, sexism, and antisemitism - prevail in many of the refugees' home countries. ${ }^{4}$

Do refugees hold views similar to those of the majorities in their home countries? If so, are they prepared to change these views, or have they already changed them as a result of their new social, legal, and economic environ-

3 European Foundation for Democracy, ed., Refugees in Europe. Review of Integration Practices \& Policies (Brussels: European Foundation for Democracy, 2018), https://emnbelgium.be/sites/ default/files/publications/2018-Refugees-In-Europe-Full-Version.pdf, 17.

4 Poll results show high levels of appreciation for a number of anti-democratic attitudes and outlooks that are critical of the rule of law, in particular in predominantly Muslim countries. At the end of 2011/beginning of 2012, honor killings of women were viewed as possibly justified by $71 \%$ in Iraq and $74 \%$ in Afghanistan. Thirty-two percent and $34 \%$ of the Iraqi and the Afghan populations respectively denied women the right to decide for themselves whether to wear a headscarf. Fifty-five percent and $75 \%$ of the Iraqi and the Afghan populations respectively are convinced that the lifestyles of most compatriots reflect the Hadith and Sunnah (canonical tales of the life of Mohammed), with corresponding approval rates for the statement, "The Sharia is the revelation of the word of God" (69\% in Iraq and 73\% in Afghanistan). Consequently, a large majority in both countries stated that sons should inherit more than daughters. Seventyseven percent of those polled in Iraq agreed that a wife should not have the right to divorce, and $53 \%$ completely agreed with the statement that a woman should always have to comply with her husband; a further 39\% overwhelmingly agreed. Approval rates in Afghanistan were even higher. Homosexuality was considered morally wrong by $77 \%$ of Iraqis. Forty-one percent in Iraq and 79\% in Afghanistan favored the death penalty for leaving Islam. See Pew Research Center, "The World's Muslims: Religion, Politics and Society," April 30, 2013, https://www. pewforum.org/2013/04/30/the-worlds-muslims-religion-politics-society-overview/. On antisemitic positions in many of the refugees' countries of origin, see "ADL GLOBAL 100," Anti-Defamation League, issued 2014, accessed October 1, 2017, https://global100.adl.org/; and Pew Research Center, Little Enthusiasm for Many Muslim Leaders: Mixed Views of Hamas and Hezbollah in Largely Muslim Nations (Washington: Pew Research Center, 2010), https://www.pewresearch. org/wp-content/uploads/sites/2/pdf/268.pdf. 
ments? ${ }^{5}$ Instead of generalization and speculation, a closer look and empirical research are called for.

Almost 1.5 million people applied for asylum in Germany between the beginning of 2014 and July 2017. All applicants have their own story, which varies considerably depending on the country of origin among other factors. Most applicants come from Syria (34\%), Afghanistan (12\%), and Iraq (10\%). ${ }^{6}$ Of the Syrian refugees, 29\% identify as Kurds, and 91.5\% have a Muslim background. ${ }^{7}$ Syrian nationals are currently the third-largest group of foreign nationals in Germany, preceded by Turkish and Polish nationals. ${ }^{8}$ With wars and unrest in many of these countries ongoing, with entire towns and parts of major cities destroyed, prospects for a better life in Germany remain. Thus, it is likely that a large number of refugees, perhaps the majority, will stay in Germany for the foreseeable future.

Taking stock of the situation at hand is crucial for developing effective private or state-funded programs for successful integration. Initial steps have already been taken, both by refugees themselves and by local populations and authorities, with a remarkable number of German volunteers providing support to refugee arrivals. The German Federal Agency for Employment (Bundesagentur für Arbeit) has developed a program for assessing the professional qualifications

5 Bassam Tibi has devoted a book of 460 pages to this question, which calls for a reform and Europeanization of Islam, as well for critical engagement with authoritarian modes of thought; see B. Tibi, Islamische Zuwanderung und ihre Folgen-Wer sind die neuen Deutschen? (Hannover: ibidem-Verlag, 2017).

6 Based on additional data from: Bundesamt für Migration und Flüchtlinge, Aktuelle Zahlen zu Asyl (Nuremberg: Bundesamt für Migration und Flüchtlinge, 2017), https://www.bamf.de/Share dDocs/Anlagen/DE/Statistik/AsylinZahlen/aktuelle-zahlen-zu-asyl-juli-2017.pdf?_blob=pub licationFile\&v=5; idem, Das Bundesamt in Zahlen 2016: Asyl, Migration und Integration (Nuremberg: Bundesamt für Migration und Flüchtlinge, 2017), https://www.bamf.de/SharedDocs/Anlagen/DE/ Statistik/BundesamtinZahlen/bundesamt-in-zahlen-2016.pdf?_blob=publicationFile\&v=16; idem, Das Bundesamt in Zahlen 2014: Asyl, Migration und Integration (Nuremberg: Bundesamt für Migration und Flüchtlinge, 2015), https://www.bamf.de/SharedDocs/Anlagen/DE/Statistik/Bundesamtin Zahlen/bundesamt-in-zahlen-2014.pdf?_blob=publicationFile\&v=14. Because of further migration, many of the people applying for asylum during this time may no longer reside in Germany; see H. Brücker, N. Rother, and J. Schupp, eds., IAB-BAMF-SOEP- Befragung von Geflüchteten: Überblick und erste Ergebnisse (Nuremberg: Bundesamt für Migration und Flüchtlinge, 2016), http://www. forschungsnetzwerk.at/downloadpub/2016_fb29-iab-bamf_soep-befragung-gefluechtete.pdf, 18-19. 7 First-time applicants in 2016, Bundesamt für Migration und Flüchtlinge, Das Bundesamt in Zahlen 2016, 24-25.

8 “Zahlen für 2016," Statistisches Bundesamt, issued 2017, accessed September 1, 2017, https:// www.destatis.de/DE/ZahlenFakten/GesellschaftStaat/Bevoelkerung/MigrationIntegration/Mi grationIntegration.html. 
of refugees. ${ }^{9}$ Schools have set up special "welcome classes.” Countless state-led and private initiatives and projects have been established to improve language skills, the housing situation, health services, trauma treatment, and cultural exchange. The extent to which these initiatives are able to address the most pressing problems facing refugees often depends on how much help is offered by individuals and in the local environment as well as on the continuation and adaptation of these initiatives. ${ }^{10}$

One factor complicating the integration of refugees is the fact that parts of the German population demonize immigration groups, sometimes going so far as to attack refugees and their homes; this bitterness is evidenced by a continuously updated chronicle of anti-refugee incidents and statistics from the Federal Criminal Police Office (Bundeskriminalamt, BKA). The latter shows that refugees often also become victims of crimes committed by other immigrants. ${ }^{11}$

Representative surveys by the Federal Office for Migration and Refugees (Bundesamt für Migration und Flüchtlinge, BAMF) show that a large majority of recent refugees support democracy and the rule of law in general terms. ${ }^{12}$ Another poll of 779 refugees from Syria, Iraq, Eritrea, and Afghanistan in Bavaria shows that over $70 \%$ of refugees from Syria and Iraq reject the statement: "Following the laws of my religion is more important to me than obeying the laws of the state."13 Eighty-nine percent of the Syrian refugees questioned spoke out in favor of "respecting" both religious and non-religious individuals. Ninety-seven percent of the refugees reject religiously motivated violence.

9 For example, the Bundesagentur für Arbeit offers the program "Perspektiven für Flüchtlinge" (Perspectives for Refugees) to assess practical knowledge among refugees in preparation for the job market.

10 For a review of best practices, see European Foundation for Democracy, Refugees in Europe. 11 Cf. "Chronik flüchtlingsfeindlicher Vorfälle," Mut gegen rechte Gewalt, accessed June 22, 2018, https://www.mut-gegen-rechte-gewalt.de/service/chronik-vorfaelle. In 2015, the Federal Criminal Police Office registered 1,031 criminal offenses against refugee shelters and houses. The numbers dropped to 995 in 2016 and to 312 in 2017. In 2017, 46,057 refugees were victims of criminal offenses. This number represents $5 \%$ of all criminal offenses. Thus, refugees, who are less than $2 \%$ of the population, were more likely to become victims of criminal action. However, perpetrators were also often refugees or migrants. In only $15 \%$ of criminal offenses against refugees were the suspects German, cf. Bundeskriminalamt, Kriminalität im Kontext von Zuwanderung Bundeslagebild 2017, issued May 8, 2018, https://www.bka.de/SharedDocs/Downloads/ DE/Publikationen/JahresberichteUndLagebilder/KriminalitaetImKontextVonZuwanderung/Kri minalitaetImKontextVonZuwanderung_2017.pdf?_blob=publicationFile\&v=4, $53-56$.

12 Brücker, Rother, Schupp, IAB-BAMF-SOEP-Befragung von Geflüchteten, 55-59.

13 S. Haug et al., Asylsuchende in Bayern: Eine quantitative und qualitative Studie, Abschlussbericht (Munich: Hanns-Seidel-Stiftung, 2017), https://www.hss.de/download/publications/Asylsu chende_in_Bayern.pdf, 66-69. 
With respect to antisemitism, a topic that was unfortunately only covered by one item, the study found alarming approval rates. Fifty-two percent of Syrian respondents and 54\% of Iraqi respondents concurred with the statement: "Jews have too much influence in the world." 14 Among the German population, the approval rates have varied between $15 \%$ and $25 \%$ in recent years. ${ }^{15}$ The level of approval among refugees does not depend on variables like age, marital status, level of education, duration of stay in Germany, or the extent to which one identifies as religious. However, it does depend on religious affiliation. Over $50 \%$ of Muslims concurred with that statement, showing a much higher approval rate than Christians, of whom only $22 \%$ concurred. ${ }^{16}$ As part of the same study, detailed interviews were conducted with 12 refugees, among them four from Syria and four from Iraq. The respondents themselves did not express any antisemitic views, but they mentioned the existence of negative attitudes toward Jews in their respective home countries. ${ }^{17}$ In a different qualitative study, 25 refugees from Syria, Afghanistan, and Iraq were asked about their attitudes toward Jews; the authors of the study detected a type of "routine anti-Zionism," "which holds Israel responsible for all the negative developments in the region," as well as a routine antisemitism, constituted by negative attitudes toward Jews that are seen as a matter of course. ${ }^{18}$ The majority of respondents in this study expressed antisemitic views, with one interviewee explicitly stating that she hates Jews.

A survey in Berlin of 445 refugees from Afghanistan, Iran, Iraq, and Syria revealed that $14 \%$ would not like to live next door to a Jewish family from Israel (only $4 \%$ would not like to live next door to an African family, but $43 \%$ would not like to live next door to a gay couple). ${ }^{19}$ A study based on interviews

14 Ibid.

15 Deutscher Bundestag, Bericht des Unabhängigen Expertenkreises Antisemitismus, Drucksache 18/11970, issued April 7, 2017, https://dip21.bundestag.de/dip21/btd/18/119/1811970.pdf, 63; “ADL Global100," Anti-Defamation League, issued 2015 and 2016, accessed October 1, 2017, https://global100.adl.org/.

16 Haug et al., Asylsuchende in Bayern, 66-69.

17 Ibid.

18 S. Arnold and J. König, Flucht und Antisemitismus: Erste Hinweise zu Erscheinungsformen von Antisemitismus bei Geflüchteten und mögliche Umgangsstrategien: Qualitative Befragung von Expert_innen und Geflüchteten (Berlin: Berliner Institut für empirische Integrations- und Migrationsforschung (BIM), 2016), https://www.bim.hu-berlin.de/media/Abschlussbericht_Flucht_ und_Antisemitismus_SA_JK.pdf, 29.

19 R. Freytag, Flüchtlinge 2016: Studie der HMKW zu Demokratieverständnis und Integrationsbereitschaft von Flüchtlingen 2016 (Berlin: Hochschule für Medien, Kommunikation und Wirtschaft, 2016), https://www.hmkw.de/fileadmin/media/downloads/pdfs/Publikationen/HMKW_Fl\%C3\% BChtlinge_2016_Studie_Ronald_Freytag_20160815.pdf. 
with 18 teachers and two caregivers for minor refugees, and another study based on interviews with five experts working with recent migrants and 24 experts (from public authorities, research and education, Jewish and Muslim organizations, and politicians), provides anecdotal evidence that strong antisemitic attitudes exist among some refugees. ${ }^{20}$

Negative attitudes toward Jews are the societal norm in Syria and Iraq. A poll conducted in mid-2013 showed that $92 \%$ of those polled in Iraq concurred with at least six of the eleven antisemitic statements presented. Seventy-five percent considered the statement that Jews are responsible for the majority of wars in the world to be "probably true." Eighty-four percent were convinced that Jews held too much power in the business world..$^{21}$ Antisemitic propaganda and incitement against Israel has long been the official party line of the Baath Party in Iraq (in power until the toppling of Saddam Hussein), which identifies as anti-imperialist, revolutionary and Arab nationalist. In Syria, the Baath Party and the regime continue in this vein. ${ }^{22}$ Such attitudes are also reflected in the educational system and in schoolbooks, which in Syria continue to contain anti-Zionist, antisemitic, and anti-American incitement. The picture presented of Germany in Syrian history schoolbooks is also problematic. In these, Hitler is portrayed as a

20 M. Kamp, “Vorurteile abbauen, Vielfalt schätzen: Ein Projekt für Geflüchtete,” in Discover Diversity: Politische Bildung mit Geflüchteten, ed. A. Demirel and D. Hızarc1 (Berlin: Kreuzberger Initiative gegen Antisemitismus, 2017), https://www.vielfalt-mediathek.de/data/kiga_discover_ diversity_vielfaltmediathek.pdf, 36; M. Berek, Antisemitism and Immigration in Western Europe Today. Is there a connection? The Case of Germany (Birkbeck: University of London, 2018), 72 and n. 80 on p. 73. Despite the anecdotal evidence, the latter study concludes that there is no connection between antisemitism and recent immigration. However, this conclusion is based on two methods that cannot establish if there is a connection or not: (1) It uses surveys that are representative for the general population, in which recent migrants are too marginal to have any visible impact, and (2) It uses statistics of antisemitic criminal offenses that do not register the share of recent migrants in any meaningful way. Although the study does not hold up to academic standards in its methods, one of the expert interviews is particularly revealing of the view of one of the mayor Muslim organizations. Mohammed Khallouk, a representative of the Central Council of Muslims in Germany that has links to the Muslim Brotherhood, argued that antisemitism simply cannot exist among Muslims because Islam does not recognize racial exclusion. He also claimed that the readiness among Muslims to accept the rights and security of other minorities largely depended on how far their own religious rights were accepted-as if this was a matter of political bargain. Cf. Berek, Antisemitism and Immigration, 77; 90.

21 “ADL GLOBAL 100,” Anti-Defamation League, issued 2014, accessed October 1, 2017, www.global100.adl.org.

22 Israel continues to be described as the enemy in the 2012 amended Syrian constitution, cf. "Qordoba - Translation of the Syrian Constitution Modifications 15-2-2012," issued February 15, 2012, accessed March 8, 2018, https://de.scribd.com/doc/81771718/Qordoba-Translation-ofthe-Syrian-Constitution-Modifications-15-2-2012. 
strong leader, defending Germany against the Jews, who allegedly enriched themselves during the Great Depression of 1929. Jews are portrayed as the eternal enemies of Muslims and Arabs, as well as humanity as a whole. Zionism and Israel are demonized in these books as imperialist and responsible for all the problems in the Middle East. ${ }^{23}$

\section{Methods and Sample}

In December 2016, 16 group interviews with 68 refugees from Syria and Iraq were conducted in Berlin. The interviews lasted approximately 90 minutes each and were conducted with the help of one female and three male translators who were also refugees from Syria: one female Arab Muslim, one male Arab Christian, one male Arab Muslim, and one male Kurdish Muslim. All interviews were conducted in Arabic, with the exception of one in Kurdish and two in English. All interviews contained parts that were conducted in German. The interview questions were translated into Arabic and Kurdish as applicable and the answers translated into English. The sample contained separate groups of refugees: refugees over/under 27 years of age, women, men, Arabs, Kurds, Palestinians from Syria, and mixed groups. All interviews were conducted by the author, who introduced himself as an academic researcher from both Indiana University and the University of Potsdam.

Contact with the interviewees was made through social workers in refugee support institutions and through the translators and their contacts. To avoid interviewing only those with ideological motives, a small reimbursement for expenses (20 €) was offered as an incentive for participation.

According to the social workers providing the contacts, the majority of the interviewees could be considered among the more "tolerant and open" refugees intent on integrating and communicating with the German population. It also needs to be taken into account that independent academic research is unknown

23 R. Heugel, Die deutsch-arabische Freundschaft: Deutsche Geschichte (1815-1945) in syrischen Schulbüchern (Hamburg: Kovac, 2013); A. Groiss, Jews, Zionism and Israel in Syrian School Textbooks, issued June 2001, accessed October 1, 2017, http://www.impact-se.org/wp-content/up loads/2016/04/Syria2001.pdf; J. M. Landis, Islamic Education in Syria: Undoing Secularism, prepared for "Constructs of Inclusion and Exclusion: Religion and Identity Formation in Middle Eastern School Curricula," Watson Institute for International Studies, Brown University, issued November 2003, accessed October 1, 2017, https://pdfs.semanticscholar.org/be13/112be6d2c4bee 6f487dd988b2d40dcc12978.pdf. On the newer schoolbooks in Iraq, amended since the fall of Saddam Hussein, see C. Asquith, “A New History of Iraq,” The Guardian, November 24, 2003, https://www.theguardian.com/education/2003/nov/25/schools.schoolsworldwide. 
under the dictatorial regimes of the refugees' countries of origin. Additionally, at the very least for the duration of their asylum proceedings, which also contain an "interview," the refugees are very dependent on the German welfare state. This may have led to an underrepresentation of individuals who presume they hold socially unacceptable attitudes toward Jews or Islam. ${ }^{24}$

Some of the subjects covered, like Islamist terrorism, gender equality, the conflict in the Middle East, or Jews and Israel are considered sensitive and were sometimes met with restraint, negativity, and distrust toward the interviewers and translators. The interviewer's affiliation with an American university, disclosed at the beginning of the interviews, also may have led to some reservations on the part of individuals holding anti-American attitudes. It is also possible that potential anti-democratic-and in particular antisemitic and anti-American-attitudes were not communicated openly during the interviews.

Two groups were aware prior to the interviews that the questions would focus on attitudes toward Jews, and openly hostile anti-Jewish positions were not present in those interviews. The others knew that the interviews were part of academic research on positions held among refugees in Germany.

The interviews were conducted in quiet cafés and restaurants, or in different Berlin refugee hostels, seminar rooms, or the interviewees' quarters. Following the interviews, the refugees were asked to complete a short survey on biographical data (age, profession, level of education, place of birth, religion, ethnic background, language skills, current occupation, length of stay in Germany). The interviews were recorded, then fully translated and transcribed. They were analyzed by two researchers through inductive and deductive coding with the analytical software MAXQDA in an iterative process of categorizing.

All interviewees, 14 women and 54 men aged between 18 and 52, had arrived in Germany beginning in mid-2014, with most of them arriving in 2015. Fifty-five refugees self-identified as Arabs, among them 11 identifying as Arab/Syrian-Pales$\operatorname{tinian}^{25}$ and 13 as Kurds from Syria. The clear majority were Muslims, while six selfidentified as atheists (including one with a Christian background), four as Christians, and one as Druze. Levels of education and religiosity varied extensively. The

24 In the summer of 2017, the author interviewed another 85 refugees from Syria and Iraq in Berlin, Greifswald, and Cologne for a follow-up project, as well as 20 individuals working with refugees together with three researchers from Indiana University: Haidar Khezri, Asaad al-Saleh, and Alvin Rosenfeld. These more extensive individual interviews are not the subject of this study. A first analysis of these interviews does not provide results that would contradict the present study, even if, in some aspects, especially in relation to attitudes toward Jews, a broader spectrum can be discerned, including radical, openly genocidal positions.

25 This denotes individuals who grew up in Syria. 
interviewees came from cities of diverse sizes, including Aleppo, Baghdad, Damascus, Hama, Homs, Idlib, Qamishli, and Raqqa or the surrounding areas.

\section{Attitudes toward Jews: From "A Religion like Ours" to Conspirators}

The interviews revealed a wide range of positions on Jews and Judaism. These ranged from pro-Jewish and pro-Israeli positions, to tolerance or lack of interest, to accordance with individual antisemitic stereotypes (like the image of the "rich Jew") and antisemitic conspiracy theories with genocidal tendencies, which manifest themselves in justifying the Shoah. There were also striking discrepancies between members of a respective country's majority populations and those who belong to ethnic and religious minorities. In particular, some of the interviewed Kurds from Syria showed clear signs of pro-Jewish and pro-Israeli positions. Sometimes these were interspersed with philosemitic tendencies, such as admiring Jews for their alleged power and cleverness. Interviewees with a Syrian-Palestinian background, on the other hand, proved to be particularly prone to antisemitism-not only in relation to Israel but also in their expressions of conspiracy theories.

On a positive note, there were a number of individual statements that suggested a possible shift in the perception of Israel as an enemy: Some interviewees consider Israel to be more humane when compared to IS or the Syrian regime.

While interviewees recognized the fact that Jews constitute a religious community, the fact that Jews also constitute a nation was ignored or explicitly denied. This is closely connected to the rejection of Israel as a Jewish state. But the interviews mainly showed that despite the evidence of some affinity for conspiracy theories and antisemitic thought patterns, most of the participants are currently focused on other things and are not thinking much about Jews at all. Some of the interviewees reflected on this themselves, as this quote suggests:

\footnotetext{
“They don't care about anything; they just want to live safely. Guys want to sleep with girls and to drink, too. And the guys who have their families, they just want their kids to be safe [...]. Really, we don't talk about Jews, we don't discuss this really, at all” (Inas, in her mid20s, Arab Muslim female from Damascus, Syria).
}

Some interviewees told us that they had contact with Jews, most of them in Germany, and in some cases also in their home countries. But it is questionable whether these accounts are all true. Several interviewees from the same hostel de- 
scribed their high regard for their "Jewish" social worker. When asked, the same social worker denied being Jewish or being aware of the rumor that she was.

Antisemitism usually came up only when certain topics were discussedsuch as the causes of war in the Middle East, Islamist terror attacks like the one on 9/11, the reasons behind the existence of the Islamic State, perceptions of Israel, the Holocaust, or the role of Jews in Germany before World War II. Antisemitic attitudes were immediately revealed in connection with references to the Freemasons, the Rothschild family, Zionism, and the banking and finance world. In discussions on traditional relations between Jews and Muslims, the picture was more ambivalent, on the one hand suggesting almost harmonious coexistence and religious tolerance, while on the other hand revealing a deep, eternal hatred between Jews and Muslims.

\section{Antisemitism and Religion: Islamic Antisemitism}

The interviews showed only a few examples of explicit religiously motivated antisemitism. In general, the Muslim interviewees clearly wanted to present a positive image of Islam and avoided portraying their religion as a possible source of conflict. Yet they also reproduced positions that feed Islamic antisemitic stereotypes, like the idea that "the Jews" falsified the Holy Scriptures and tried to poison the Prophet Mohammed. ${ }^{26}$ Interviewees also linked positive stereotypes about Jews to Islamic sources:

"Jews, they're capable, Jews are sons of God ... that's why they have money, and in the Qur'an, it says they're hardworking” (Nidal, 35, Kurdish male from Aleppo, Syria with a Muslim background).

The presumption of a general hatred between "the Jews" and "the Muslims" has the potential to become radical, as it extends to all Jews, including those in Germany. One such example is Yanes's reaction to Jalil's statement in a discussion on the coexistence of different religions in Germany. Jalil said that Islam was a peaceful religion and that "our Prophet Mohammed told us that we have to accept all the religions. And when they were fighting pagans, he didn't like to kill any of them because he thought, maybe that might be a believer" (Jalil, 42, Arab Muslim male from Bagdad, Iraq). On closer observation, Jalil's statement only appears to

26 Such interpretations are common among various Islamic groups. The Qur'an and the Hadith describe relations between Jews and Muslims as ambivalent. 
be tolerant, especially if applied to current relations between religious groups and atheists in particular. Yanes took issue with this pretense of tolerance:

"They [the Jews $\left.{ }^{27}\right]$ become our enemies in the end; as per the Qur'an and Islam, God tells you [...] that those are your enemies" (Yanes, 32, Arab-Palestinian Muslim male from Damascus, Syria).

Yanes was not wrong in saying that the Qur'an and the Hadith (traditions or sayings of the Prophet Mohammed) contain passages suggesting-especially in widespread but ahistorical and non-contextualized interpretations-that the Jews are the ultimate enemy of Islam and the Muslims. ${ }^{28}$ Even interviewees who do not share these views alluded to such a confrontation: "There's a very big problem between Islam and Jews. And this problem is from the time of the Prophet" (Nidal, 35, Kurdish male from Aleppo, Syria, with a Muslim background). Individual interviewees were aware of the assertion propagated in Islamist circles that Jews are descendants of monkeys and pigs, ${ }^{29}$ but they said they reject it.

As evidence of the Jews' hatred for Muslims, some interviewees cited the belief that the Jews had tried to kill the Prophet Mohammed. For example, Abia (approximately in her mid-20s, Arab Muslim female, from Baghdad, Iraq) recounts that the majority of people in Iraq do not like Jews, whom they believe do not respect the values of Muslims and who speak badly about Islam. Hayyan (approximately in his late 20s, Arab Muslim male from Quneitra, Syria) added that "the Jews" had "tried to kill" the messenger. This rumor is obviously also known to the translator of the discussion, who traces it to the canonical Hadiths, the accounts of the actions and words of the Prophet Mohammed, which include a story of a female Jewish slave who is said to have offered poisoned meat to Mo-

27 Upon the translator's request for clarification of who Yanes identified as the enemy, Yanes replied "Israel," making it clear that he was not referring to nonbelievers in general. As the previous discussion had mainly revolved around Jews in general and Yanes had already stated that he does not differentiate between Jews and Israel, his statement and its reference to the Qur'an would make no sense if applied to Israel and not Jews; thus, it can be inferred that he does in fact mean Jews.

28 Of particular relevance among a number of anti-Jewish passages in the Qur'an, the following can be mentioned: Qur'an 5:82, stating that the most bitter enemies of Muslims are to be found among the Jews, much more so than among Christians; Qur'an 2:88, describing how God put a curse on the Jews; Qur'an 2:96, accusing Jews of enjoying the secular life; as well as Qur'an 9:29, calling for a fight against Jews and Christians, until they pay tribute and show submission. The canonical Hadiths contain more explicitly anti-Jewish passages.

29 N. J. Kressel, "The Sons of Pigs and Apes": Muslim Anti-Semitism and the Conspiracy of Silence (Dulles: Poto-mac Books, 2012). 
hammed..$^{30}$ Islamists, and in this case also one of the participants, infer from this story that "the Jews" have been the mortal enemies of Muslims ever since the times of the Prophet.

One of the most powerful accusations against "the Jews" in Islamic tradition -in many ways similar to the Christian accusation that "the Jews" killed Jesusis the assumption that "the Jews" falsified the Holy Scriptures. This accusation can be found in a number of passages, including some in the Qur'an. ${ }^{31}$ Stereotypes of "the Jews" as liars and traitors are linked to this accusation.

"What do we know about Jews? [...] A religion for sure, but they falsified it. [...] This is what we know. [...] They have a book like us and they have a prophet, and we recognize their prophet and everything, but they falsified the book that was revealed by God. [...] And the Qur'an also said it is not the same book" (Bader, 33, Arab-Palestinian Muslim male from the Yarmouk refugee camp close to Damascus, Syria).

Akram turned the accusation on its head: "There are a lot of Jews thinking about us as, 'This is my enemy,' and say we falsified the Qur'an” (Akram, 26, Arab-Palestinian Muslim male from Damascus, Syria). Even the wish for the destruction of Israel can be justified in religious terms, by declaring "Palestine"-which in these views includes the territory of Israel-Muslim territory to which Jews and the Jewish state can claim no sovereignty.

"At the end Palestine is ours. We are Muslims and we know that Palestine belongs to Muslims and Arabs and that Aqsa [the Dome of the Rock in Jerusalem] is for us and that one day, Palestine will be free and will return to us" (Yasser, 41, Arab-Palestinian Muslim male from Homs, Syria).

Inas and Fatin, both young, secular, hardly religious women from Damascus, mentioned a belief held within their circles of friends and family and propagated in schools and school books in Syria: "I heard in Islam that before the doomsday, we will get Palestine back and we will win the war" (Inas, approximately in her mid-20s, Arab Muslim female from Damascus, Syria).

30 Sahih Muslim 26:5430 and Sahih Bukhari 3:47:786.

31 From a theological perspective, the problem for Islam is that the Qur'an counts as God's direct word, and it includes several stories from the Torah or the Old Testament but changes some of them, in some cases even significant details. If the text of the Qur'an counts as absolute truth, the Torah has to be a falsification of these stories, even if it is historically uncontested that the Torah originated long before the Qur'an and transcripts exist that pre-date Islam. The accusation of falsification can be found in the Qur'an, for example in 4:46 or in 2:75, where Jews are accused of having intentionally distorted God's words. 
This assumption shows the intricate mix of secular, Islamic, and nationalist interpretations of a war against Israel or against "the Jews," as the case may be. It can be linked to the delusion widely held in Islamist circles of a global war against Islam that, if not led by "the Jews," is at the very least supported by them. In this conception, there will be a religious war before Judgment Day, a war that Islam will win. ${ }^{32}$ As proof of this belief, Gamal, a former school principal and university professor, cited The Protocols of the Elders of Zion, from which he recited from memory: "We did our best to end Christianity in Europe and to restrict it inside the Church. [...] And it won't take us a long time to finish Islam" (Gamal, 45, Arab Muslim male from Idlib, Syria). In Gamal's view, the ever-present accusation that "Islam" is the cause of terrorism proves the authenticity of The Protocols of the Elders of Zion, which he said is a "Jewish book." He owns two copies.

Some interviewees explained their animosity toward Jews as being part of Muslim tradition. For example, Inas remembers Muslim rules of conduct toward Jews and Christians.

"I hear that Jews are like us. They are clean like Muslims. [...] But you cannot sleep in their houses because you cannot be safe. Christians are not clean, but you can sleep in their houses. But Jews are our cousins because they are like us in habits and ... you know, the normal lifestyle, we are the same” (Inas, approximately in her mid-20s, Arab Muslim female from Damascus, Syria).

\section{Anti-Israelism (Anti-Zionism): Against Israel's Existence}

For most of the refugees interviewed (with the exception of most Kurdish participants), it is considered normal to hold negative attitudes toward Israel and to believe that the existence of the State of Israel is illegal and should end. Accordingly, Zionism is almost always viewed negatively. It is also a term that is used to denote any number of fantasies about alleged Israeli influence in the world, as well as Israel's alleged plans for territorial expansion. In other words, Zionism is not simply seen as a national movement for the establishment of a Jewish state. The simplistic black and white anti-Israel sentiment, generalizing and oversimplifying issues while offering no criticism of individual positions of the Israeli

32 R. L. Nettler, Past Trials and Present Tribulations: A Muslim Fundamentalist's View of the Jews (Oxford: Pergamon, 1987). 
government, reflects a fundamental opposition to the State of Israel out of principle; at stake is not criticism but antisemitic hostility. For most interviewees, perceptions of Jews on the one hand and Israel/Israelis on the other hand often overlap, even for those who insist that there is a significant difference between Jews and Israelis.

Those with anti-Israel views position themselves as pro-Palestinian (even if they personally do not have a Palestinian background); ${ }^{33}$ at the same time, their rejection of Israel is not so much related to Palestinian suffering as it is a question of principle: just the existence of a Jewish state on allegedly Arab or Muslim territory is seemingly unacceptable to them.

Interviewer: "Do you think that it is a bad idea that Israel exists?"

Gamal: "Yes, of course." (45, Arab Muslim male from Idlib, Syria)

For Gamal, it is simply normal to deny Israel's right to exist. It is interesting to note that he qualified his above statement with the sentence, "But not worse than Bashar al-Assad." Some Syrian interviewees do recognize that the crimes committed by the Syrian regime and IS are more serious than any crime allegedly committed by Israel. "Israel in its criminal history in Palestine did not kill people as much as Bashar al-Assad killed in six months in Syria!” said Burhan (27, Kurdish Muslim male from Damascus, Syria), who himself is far from being free of anti-Israel conspiracy theories. However, his responses show some evidence of a shift in the perception of Israel as an enemy. Other participants like Gamal prefer to see a conspiracy at work: Gamal described Bashar al-Assad as a "partner" of the Islamic State. His reasoning: Both do not fight Israel, even though Israel attacks Syria. For Gamal, this suggests that all three act together. Others, however, are convinced that Syria is being attacked "to protect Israel" (Zaid, 29, Arab Muslim male from Syria). That Israel is behind the wars in Syria and Iraq is a belief shared by secular and religious, Christian and Muslim, female and male interviewees. Some are more likely to point to the (negative) regional influence Israel holds and to highlight Israeli attacks on Syria and the occupation of the Golan Heights or South Lebanon, which they consider to be parts of a plan dating back to 1948 or even earlier to create a Greater Israel.

"As for Israel, even though they seem compact and do not say anything about all the problems in the region, their plans, which date back to 1948, extend beyond Palestine. They

33 Interviewees of Palestinian background often stressed their Palestinian identity, and they consider it natural to hold anti-Israel positions, without having to refer to the suffering of Palestinians and Israeli responsibility. 
really wanted to get rid of Syria since the war of October [reference to the Yom-Kippur war of 1973]. It is also better for them to get rid of Syria, because Syria or Iran is always confronting them, so they want to remove religion from the equation. They will also be there creating problems. In my opinion, Israel has a very huge influence over what's happened" (Jaleel, 31, Arab Christian male from Damascus, Syria).

Other interviewees assigned Israel a passive but cynical role in the Syrian war

“Israel hasn’t done anything, it’s just watching us. It doesn't have to interfere because Arabs are killing each other and Syria and Iraq and Libya were destroyed, and Israel is happy like this” (Yasser, 41, Arab-Palestinian Muslim male from Homs, Syria).

The main reason cited by participants for their anti-Israel views is their condemnation of the "occupation of Palestine"-a position they assume is widely shared, including the interviewer. It must be noted that this term does not refer to the occupation of the West Bank but to the actual founding of the State of Israel. The Syrian and Iraqi regimes often use state propaganda to influence perceptions of the Jews, as evidenced by Assad's reflections on the time before he came to Germany: "I didn't know much about Jews; all I knew is the Jews are occupying Palestinian lands” (Assad, 31, Arab Muslim male from Homs, Syria). ${ }^{34}$

When asked directly whether Israel has a right to exist, Zaim replied with a rhetorical question, which was supported by the other participants of the group interview from Syria and Iraq:

"If we assume the Russians, as an example, came and occupied parts of Germany and stayed in it, now, after 40 or 50 years will they have the same right to live on the same land exactly like the Germans?" (Zaim, 20, Arab-Palestinian Muslim male from Raqqa, Syria).

For ideological reasons, many interviewees denied the historical truth that Jews lived in the Middle East long before the State of Israel was established. Jews are perceived to be European only and therefore alien to Arab territory.

Interviewer: But don't you think that Jews were in Jerusalem and Hebron, like 2,000 years ago?

Yasser: "Who? Jews? No, Jews were in Britain, Jews' home is not Palestine. [...] Jews don't have a home, they don't have a country...” (41, Arab-Palestinian Muslim male from Homs, Syria)

34 Assad rejected antisemitic conspiracy theories offered by other participants and showed little resentment toward Jews. He believes that his Jewish acquaintances in Germany are the ones who taught him that the stereotype of the "rich Jew" who "owns everything" is, in fact, true. 
Yasser rejected the Jews' right to national self-determination more than the argument that there is no history of Jewish life in the Middle East. He took the argument one step further by proclaiming that Jews did not have the right to have a country of their own and related back to the stereotype of the rootless, ever-wandering Jew. ${ }^{35}$ Interviewees recognized the historical fact that Jews have been living for centuries not only in Jerusalem but also in Iraq and Syria. From their perspective, however, this fact only serves to reinforce the idea that a harmonious coexistence is only possible under Arab or Muslim leadership. Ultimately, this belief leads to a call for a destruction of the Jewish state in favor of a Muslimor Arab-dominated Palestine, in which Jews would be tolerated. One proponent of this position is Zaid:

\begin{abstract}
"In our Arab mentality there is no peace if you don't give back what was taken. [...] What I want is that their army will be ended, and they may continue to live on our land, to practice their religion. [...] This is what we want for the next 25 years. Inshallah. And I will repeat it for the third time, we will decide for the whole Arab nation's future, even if there will be a third or a fourth world war, because we have a big generation raised on this culture. We don't have any problem with Jewish people, we believe this is [also] their country, their region, but we want to end the Israeli army and it will be finished. And they may live with us, under the Palestinian country practicing their Jewish religion without any problem. We just want to live in peace and security” (Zaid, 29, Arab Muslim male from Syria).
\end{abstract}

The fundamental rejection of the Jewish state was also evident in the way some of the more Western-oriented interviewees rejected the official name of Israel and instead used the term "Palestine." Inas, already quoted before, said this: "For me it's a dream to go and see Palestine. Really, it's a dream for me." When asked whether she was referring to Israel or Palestine, she responded in a friendly but firm way: "No, no, it’s Palestine. Palestine and something called Tel Aviv" (Inas, approximately in her mid-20s, Arab Muslim female from Damascus, Syria).

The Christian stereotype of Jews as child murderers has been handed down since the Middle Ages, and in contemporary discourse it is often applied to Israel. During the interviews there were some isolated references to the emotional

35 Yasser is a good example of someone who tries to differentiate between Jews and Israel. Despite his fundamental opposition to Israel, denial of a Jewish nation and its connection to Israel, and his use of anti-Jewish stereotypes, he still said, "We are not against Jews. Some people are good and some are bad. Netanyahu is a bad person, but not all the citizens are" (Yasser, 41, of Palestinian-Syrian origin from Homs, Syria). Jaleel, quoted above recounting a conspiracy theory about Israel's alleged responsibility for the destruction of Syria, offers another rather unoriginal conspiracy fantasy on the events of September 11, 2001, claiming that 3,000 Jewish employees did not show up for work that day, only to continue: "I have three very nice Jewish friends here, so this is only about the governments" (Jaleel, 31, Christian from Damascus, Syria). 
image of the "child murderer Israel": "Palestine is under occupation, and children and people are being killed for sixty years now," said Safeer (49, Arab-Palestinian Muslim male from the refugee camp Yarmouk close to Damascus, Syria). The image of the "child murderer Israel" with its emotive power was rarely evoked, though. This may have to do with the fact that when the interviews were conducted in December 2016, media coverage on the Middle East conflict provided virtually no images to support this stereotype, while images of Syrian children killed in gas attacks were still very much on participants' minds. Another likely reason is that the suffering of the Palestinians is not central to every interviewee's rejection of Israel. On the whole, it is evident that the Israeli-Arab conflict has much greater significance for interviewees with a Palestinian background, who discussed the issue much more emotionally. For other interviewees, the Israeli-Arab conflict is less significant in light of the wars in Syria and Iraq.

When the participants were asked whether they believed that what the Nazis did to the Jews was the same as what Israel is doing to the Palestinians, there was a wide range of reactions. There was an almost even split between those who agreed with the comparison and those who rejected it. Agreeing that events in Israel are even worse than the Holocaust often went hand-in-hand with a fundamental rejection of Israel's right to exist; this also seemed to be the main factor in agreeing with the comparison, as there was no attempt to compare specific aspects of the Holocaust with the current situation in Israel. Instead, "the Holocaust" is used as a symbol. More than one participant refused to answer this question, as it is perceived to reflect a pro-Israel bias.

Hassan, who did not want to reveal his opinion, claimed to speak on behalf of "Muslim and Arab young people" who generally oppose Israel, and he noted that he sees similar opposition among some Germans:

“I can't give an evaluation whether I'm with or against Israel. [...] But regardless of the definition or the evaluation, our Muslim and Arab young people have that idea that they don't want Israel as a government, not as people. There are even German people who declare that Israel is wrong” (Hassan, 39, Arab Muslim male from Iraq).

Others were less restrained in their evaluations. Yanes considers the atrocities committed by Israel to be worse than the Holocaust:

\footnotetext{
"Israel is doing worse than that, like bombing and killing and displacing people and destroying, and all of this is being done to build the state of Israel and to protect it. [...] It's worse than the Holocaust" (Yanes, 32, Arab-Palestinian Muslim male from Damascus, Syria).
} 
In his case, as well as in Hassan's, it is clear that his main goal was to disavow Israel.

Vaguely equating the actions of the Israeli government against Palestinians to the extermination of the Jews may well be rooted in a lack of knowledge of both the Holocaust and the Israeli-Palestinian conflict, coupled with a fundamental rejection of violence. "Murder is murder" was the response of many, when asked for their opinions on the comparison between Nazis and Israelis. This mindset could very well form a basis for educational measures. But the comparison may also be rooted in other hostile attitudes, as in Jawad's case, who is convinced that Israelis and/or Jews have a tendency to be brutal because of their experience of the Holocaust.

"If you ask a psychologist about a child who is always making trouble and beating the
other children, he will find that his father or someone else treated him with violence.
[...] The fear and surviving culture push them to kill others and justify this to themselves."
Translator: "You mean that what Israel is doing to Palestinians is equal to what Germans
did to Jews?" Jawad: "Of course, because killing is killing. If you enter a peaceful land ..."
(Jawad, 34, Arab Muslim male from Syria).

At the same time, rejecting the Nazi-Israel comparison does not necessarily mean that the founding of the State of Israel is considered legitimate, at least if certain parallels are still being drawn. Dila (26), an atheist Kurdish woman from Syria, said that the actions of Israelis and those of Nazis stem from "the same idea, but in a different way. The Israelis stole the land, even if they didn't kill so many people and Hitler killed so many people.” Interestingly, the comparison was often rejected by members of minority groups, in particular Kurds but also some Christians and atheists, and quite strongly in some cases.

Dalal (18), a young female Christian from Homs, Syria, explained: "I think that the Nazis were worse, they're really much worse. Also, everything that happened in Palestine, it's not like what happened to Jewish people.” Burhan (27), the only Kurdish participant in one group interview, agreed with the others that Jews are rich and the banks belong to them, but he rejected the comparison of Israelis to Nazis, "because Israel has more mercy with Palestinians than Hitler had with them. Israel and the Jews with all their rudeness, they did not do in Palestine one per cent of what they faced in Germany." Even Sayid (20), a young Arab Muslim male from Hama who does not belong to any minority group in Syria, offered quite a multi-faceted view of the Israeli-Palestinian conflict. In another interview, he also rejected the comparison: "In case you would like to know who is worse between Hitler and Israelis, I certainly would say Hitler.” Rejecting the comparison of Israel with Nazi Germany often does not seem contingent upon any specific knowledge about the Holocaust or the Israeli-Pal- 
estinian conflict. Rather, it depends upon whether there is a prevailing hostility against Israel and Jews. Siyamend, a 22-year-old Kurdish male from Qamishli, Syria, said: "It's not the same, because what we learned about Israel of Palestine, and I don't really know the true story, but we learned that the Israeli army took their land. But here [in Germany], there were holocausts; I mean, the two cases are completely different." And Shaheen, 26, another participant in the Kurds-only group interview, agreed with him, even though he referred to Arab TV channels that generally report negatively about Israel: "Sure there are violations of the rights of the Palestinians in Israel, as we have seen on Arab TV channels, for example when it comes to housing and things like that. But I don't think we can compare that to the genocides that were here."

Hayyan, an Arab Muslim male from Syria, approximately in his early 30s, has his own personal reason for rejecting the comparison of Israel with the Nazis. He is from Quneitra in the Golan Heights, directly adjacent to Israel. His father spent two years in an Israeli prison but was treated well. And he knows, "Even now in the areas that are close to Israel, whenever there are any injured people on the borders, they [the Israelis] are taking them to give them medical assistance, whatever their treatment might cost." Hayyan appears to know nothing more about the Holocaust than other interviewees, and he denounces Israel for having (temporarily) occupied his village, but he rejects the demonization of Israel through comparison with Nazis. That Israel observes the rule of law in the treatment of prisoners in jail and in the care provided for Syrian casualties seems to have had a profoundly positive effect on Hayyan's views of Israel and Israelis.

The explicit differentiation between Israelis on the one hand and Jews on the other that can often be heard is mostly used to deny allegations of antisemitism, while at the same time legitimizing a negative attitude toward Israel: "I think Israel is something bad but the Jews are human" (Adnan, 36, Arab Muslim male from Damascus, Syria).

Some of the interviewees did make explicitly positive statements about Jews, on the condition that Jews distance themselves from Israel and thus show solidarity with "their" side. Others, however, made no distinction between Jews and Israelis: "I don't really know the difference between them, but as a Palestinian I think both of them are my enemies" (Yanes, 32, Arab-Palestinian Muslim male from Damascus, Syria). In global conspiracy theories, those categories tend to be blurred despite attempts to differentiate, as the following section illustrates. 


\title{
The "Rich Jews" and Conspiracy Fantasies to Explain the World
}

The globally spread antisemitic stereotype of the rich Jew was far more prevalent in the interviews than was any other stereotype. ${ }^{36}$ Most interviewees took it for granted that Jews simply have to be rich. This alleged fact was not necessarily viewed as negative.

"The idea that Jewish people have a lot of money, it is really common in our society. And what's the problem if they have a lot of money? Syrian merchants were taught by Jews how to manage their trades” (Qadir, 31, Arab Christian male from Damascus, Syria).

Some interviewees chose their words carefully, which showed their uncertainty: "As Arabs we think of the Jews as the richest people on earth, but this might be wrong” (Maen, 23, Arab Muslim male, Khirbet Ghazaleh, Syria). Others offered what they considered proof:

\begin{abstract}
"All the statistics that we see on social media say that most worldwide stocks and banks are owned by Jews. And it is known from ancient times that Jews make good commerce and they really know how to trade. They are an example of great businessmen. They do the sell-a-lot-and-win-little strategy, so they really are rich people” (Burhan, 27, Kurdish Muslim male from Damascus, Syria).
\end{abstract}

There was no consistency among interviewees in applying the stereotype of the "rich Jew." In general, it was simply transferred to "the Jews." Some participants spoke of "large Jewish families" controlling the "international monetary system," and of others who "own most of the biggest Swiss banks" (Qadir, 31, Arab Christian male from Damascus, Syria). The image of the "rich Jew" was also applied to Israel, embedded in conspiracy theories in which Israel and the Jews control the whole world through money.

"Israel, especially Jews are known for [being] the biggest financial power in the world, so
they are ruling the world with their money. Just yesterday I read that some Jewish doctor, I
forget his name, said that the Star Academy program was made by us, and we spread it in
the Arab world through Europe in order to humiliate the Arab woman, because the Arab
man is already humiliated. So when they told him that the program is in Lebanon, he

36 Only in one interview, two Syrian-Palestinian participants (Suaad, 27, and Sabri, 41, from the refugee camp Yarmouk close to Damascus and Homs/Syria, respectively) claimed to have never heard of the stereotype of the "rich Jew." 
[the Jewish doctor] said that it's sponsored by them, the Jews, Israel and America, so they are ruling the world with their money" (Ratib, 36, Arab Muslim male from Iraq).

The quote from Ratib illustrates how the stereotype of the rich Jew is often equated with Jewish power, which is framed as destructive and dangerous for nonJewish communities, in this case the Arabs. Zaid associates this with control of the media, politics, and the whole world:

"Jews are controlling the whole media world, even America. They're controlling the main politicians, for example, Donald Trump, the president of the US [...]. They are controlling the world because they have money, but we have the gas, the oil, and everything” (Zaid, 29, Arab Muslim male from Syria).

The interviewees see secret conspiracies of alien powers at work in any number of circumstances. Often-but not always-they suspect that Jews are pulling the strings behind it all. This was evident when the participants were asked to explain the wars in their home countries. In addition to (realistic) assessments that countries such as Russia and the United States but also Iran, Saudi Arabia, and Turkey are pursuing their own interests in Syria and Iraq, there was also speculation about the underlying issues and causes, which was rife with conspiracy theories. Alien powers were said to have caused the wars to destroy Islam, to exploit the Arab countries and get their oil, to create a market for weapons, or to force the countries' brightest minds to emigrate and then to exploit them in the workforce. These alien powers are believed to be located in the US or Israel or are simply conceived as "the Jews" in an ominous global arms industry. Explanations of this sort reveal an understanding of the world in which an all-powerful "other" is the cause of negative developments. This perspective is supported by a selective historical narrative in which the division of the Near and Middle East following the breakup of the Ottoman Empire in French and British spheres of influence is directly transferred to the present and conceived as an anti-Arab or anti-Muslim conspiracy.

"I once heard Hillary Clinton talking about the termination of Sykes-Picot Agreement, which is relating to the division of Arab countries and has the duration of one hundred years. [...] So that [in 2011] people in Arab countries would revolutionize and make another Arab Spring after its termination, so I think it's a Western, American and Israeli conspiracy on Arab countries to maintain the peace of Israel” (Sayid, 20, Arab Muslim male from Hama, Syria).

In this understanding of history, it is not individual agents with their own individual interests who influence the course of the world but dark, impenetrable powers that determine the course of history across generations according to a 
laid-out plan. It is hardly surprising, then, that this kind of thinking refers back to the tradition of antisemitic conspiracy fantasies like The Protocols of the Elders of Zion, and that "the Jews" or Israel are accused of using another country like a pawn in a game.

These conspiracy fantasies provide an unchallenged framework for interpretation of not only political and historical events but also casual, almost trivial phenomena, which are perceived as a threat to one's own community. Burhan, for example, is convinced that the computer game "Counter-Strike" was brought to Syria by evil forces to raise a new generation of coldblooded warriors for the ongoing civil war.

"The world we live in is like a chess game, and there are unknown hands that control the
pieces. They try to make us believe that our countries have fortunes and we should steal
them [...] but the truth is that they were planning for this for over a hundred years, and
still planning for the next hundred years. There is an unknown force in this world, and I
personally think that the international Mossad ... international Zionism leads the whole
world, and every country, population, every nation's destiny is in their hands, and if any
president of any country isn't satisfying the Masons they will replace him instantly with
someone who wants to do whatever they want him to do. I believe that they are behind
the suppression of populations, and behind Islamization, ISIS, and introducing Islam in
the wrong way and creating a violent generation. For example, the Counter-Strike game en-
tered Syria in 2004. It wasn't just a game they were creating a generation who is ready to
carry weapons. This game is about counters and armed desperados, it's all about war and
death, so they raised this generation on killing and using weapons and knowing about kill-
ing strategies. [...] I will tell you a story about my cousin, who was born in 1994 . In 2004 he
was ten years old, and since he was 10 years old he started to play Counter-Strike. When the
revolution started he was one of the firsts to carry a weapon” (Burhan, 27, Kurdish Muslim
male from Damascus, Syria).

Burhan is proud of the culture of Syria and laments the destruction of his country. He holds Mossad, "international Zionism," and the Freemasons responsible. It is interesting to note that Burhan's view of the world is defined by conspiracy theories, including antisemitic ones. He is convinced that Jews dominate the banks and that Jews were at least informed ahead of time of the attack on the World Trade Center on September 11, 2001, because they allegedly did not come to work that day. At the same time, this thinking is fractured at least in one respect. When the discussion turns to Israel, Burhan praises the Israeli government for looking after its own people and being more humane than the regime of Bashar al-Assad.

"Freemasons" often appear in conspiracy fantasies and are associated with Jews. This was evident in the interviews not only in the example of Burhan with his Muslim Kurdish background but also in the case of Qadir, who has a Christian background. 


\begin{abstract}
"America is Israel and Israel is America. I'm not talking about the religious correlation; however, it plays a significant role. Eventually, there is something called 'Freemasonry,' whose vast majority and founders are Jewish. The story is, Israel is the cancer that exists inside the body of the Arab countries. It's one huge factor that controls the whole region. The second thing is the image of the religions. [...] I do not care what your religion is, since it's your own private relation with God. Nevertheless, what most people have not realized is that religion has become a weapon in the hands of others instead of the hands of its own people” (Qadir, 31, Arab Christian male from Damascus, Syria).
\end{abstract}

As a member of the Christian minority in Syria, Qadir may be particularly aware of the extremist, anti-secular interpretations of Islam. He considers the lack of nationalism and the conflict between Sunnis and Shiites to be the biggest problems in the Arab world in general and in Syria in particular. In the group discussion with a majority of Muslims from Syria, he nevertheless avoided criticizing Islamism, instead referring to the alleged misuse of religion through conspiracies from the outside, possibly to avoid being accused of criticizing Islam. At the heart of Qadir's conspiracy fantasies is not only "the cancer" Israel but also the US, or, more precisely, the US as a country controlled by "the Jews" or Israel.

The attacks of September 11, 2001, often play an important role in the conspiracy narrative because they were allegedly orchestrated by the Americans and/or the Jews to legitimize the attacks on the Middle East, "the Muslims," or "Islam." Politics in America and the American president are seen as strongly dependent on the Jewish or Israeli lobby.

A conspiracy fantasy that is especially popular among Syrian interviewees consisted of an alleged secret alliance between Bashar al-Assad and Israel: The Syrian regime is said to only appear to be following anti-Israeli policies while at the same time preventing any effective measures against Israel because of their alleged links. The anti-Zionist ideology of the Syrian regime is so firmly entrenched in the minds of some refugees that, despite their opposition to the regime, they dare not question this theory.

However, there are signs that even those who believe in the crudest antisemitic conspiracy fantasies are sometimes willing to reevaluate their positions. For example, Maen (23, Arab Muslim male from Khirbet Ghazaleh, Syria) talked about a rumor he has heard that Israel or Jews control most of the media in the world and that Jewish families control most of the banks. In this context, he mentioned "The Protocols of Zion" and another conspiracy theory book, only then to state that he may not have all the facts and the books could be wrong. He also criticized as propaganda the fact that "we grew up hating Israel, and our Arab leaders are ... telling us we should hate Israel." 


\section{Distancing Oneself from Antisemitic Propaganda and Minorities' Solidarity with Jews: The Kurdish Example}

"They [the representatives of the Syrian regime] turned out to be worse than the image of the Jews they were promoting” (Shaheen, 26, Kurdish Muslim male from Syria).

Some participants explicitly rejected antisemitic stereotypes and allegations. In their rejections, however, it became apparent that such antisemitic views are the societal norm in their home countries and are spread through state propaganda. It also became clear that only some antisemitic ideas were being reconsidered, while other stereotypes and thought patterns persisted.

The following three examples of Fatin, Adnan, and Maryam show different cases of Arab interviewees distancing themselves from antisemitic positions. Fatin is a student in Germany and tends to hold very secular and tolerant positions. Her English is excellent and she speaks German well. While she still believes that Israel was behind the attacks on September 11, 2001, she has begun to question some antisemitic attitudes. This includes anti-Jewish stereotypes in everyday language and an acknowledgement of Syria's state-sponsored agitation against Israel and Jews as propaganda. She makes an effort to differentiate between Jews, Israelis, and the State of Israel.

"I used to hear it from all my old friends. If someone is really mean, they say he's Jewish. [...] [In our generation] it's a little bit better. And especially for me, after we moved out of Syria. Because, as you said: the propaganda of Syria was teaching us all the time that it's our enemy and we are not allowed to think about everything, as it is Jewish, Israeli, Zionism and they're all enemies. And then we start thinking about it when we grow up or when we move a little bit out of Syria. We start to recognize the difference between Jews and Israel” (Fatin, 26, Arab Muslim female from Damascus, Syria).

Adnan, 36, used to be the branch manager of an international fashion house in Damascus. During the interviews, he stressed that in Syria, it may sometimes be advisable to show that you are against Jews to avoid conflict with the regime. He claimed he does not have any hatred toward Jews and that, even if he himself is no expert on the matter, the Qur'an teaches respect toward Jews.

During the course of the interview, however, he also explained that the Jews became enemies through their occupation of Palestine.

"If I were in Syria right now and you would ask me my opinion about Jews, I would tell you that I hate all of them, because I would be afraid for myself. If I did not tell you this, if I told 
you the opposite, I would go to prison for ten years. [...] They teach us that Israel is the same as the Jews and that we must hate both of them. But in the Qur'an [it says] we must respect Jews” (Adnan, 36, Arab Muslim male from Damascus, Syria).

Maryam, 35, an Arab atheist female with a Christian background from Damascus/Syria, said, "you cannot depend on what has been taught at school, that Jews are greedy and have a lot of money," because "they are also human beings, as I have come across some wonderful people here."

None of these three interviewees is particularly religious, and they all come from Damascus, a considerably pluralistic and large city. All three emphasized that Syrian propaganda is not solely aimed at Israel but at Jews in general. Fatin also described antisemitism in everyday language. Each of them had different reasons for reconsidering their previous antisemitic attitudes: for Fatin, it was simply being geographically far away from Syria; in Adnan's case, it was because he no longer faced the Syrian regime's coercion to antisemitism, along with his tolerant understanding of Islam; for Maryam, it was her encounters with Jews in Germany.

Among Kurdish participants, antisemitic stereotypes and conspiracy fantasies were generally less prevalent, even if counterexamples exist and are also quoted in this report. If Kurds voiced antisemitic positions, it was more likely to happen in mixed Arab-Kurdish groups than in Kurdish-only groups. In part, this may have to do with an instrumental use of antisemitic images: Adapting to the prevailing (antisemitic) discourse may make it possible to argue for Kurdish interests against the majority positions. In groups consisting of Kurdish participants only, some drew parallels between their people and Jews or Israel because of the perception of a shared enemy ("the Arabs," or the states Iraq, Syria, and Turkey). Others saw parallels between the Holocaust and Saddam Hussein's gas attack against Kurds in 1988 in Halabja and other cities. ${ }^{37}$

Nidal, a 35-year-old Kurd and former teacher from Aleppo, not only described the lack of hatred between Kurds and Jews but also spoke of a secret love that can be seen in the way that Jews have helped Kurds. He sees parallels in the history of the Kurdish and the Jewish peoples, equating the killing of thousands of Kurds in Saddam Hussein's gas attacks with the Holocaust. His image of Jews is shaped by philosemitism: because of God's gifts, the Jews are supposedly particularly capable and rich.

37 A Christian participant, possibly with an Armenian background, drew parallels between the Holocaust and the genocide of the Armenians, though this did not stop him from believing in antisemitic conspiracy fantasies about the Freemasons and Jews allegedly dominating them. 
"We knew, we were told that Jews helped [Kurds]. [...] A kind of love grew, but it was a love that was hidden. [...] How did we know that it was wrong [how people speak about Jews] in Syria? We knew it wasn't correct because, all the time ... the things you said and did weren't the same. [...] I mean we viewed Jews like we viewed ourselves, for instance, the things they had been through in the Second World War, and Halabja, Anfal, these were the same. Well, and Jews, they're capable, Jews are sons of God ... that's why they have money" (Nidal, 35, Kurdish male from Aleppo, Syria with Muslim background).

Siwar described a clear difference between Arabs who are said to be against Jews and would even support murdering Jews, and Kurds who are said not to share this hatred. He even mentioned inconsistencies in Syrian educational programs related to Israel, as they mention the historical Jewish settlement in Canaan but accuse today's Jews of occupying Arab land.

"What is the difference between Kurds and Arabs in Syria in terms of Nazis and in terms of Germany? Well, for example, Arabs despise them [the Jews], and they're amused by that type of killing. Thousands of people were killed and they were amused by it, but Kurds aren't like that. Because there's no hostility between us and Jews, Jews are a people like us, they're humans and in fact they've been through rough times [...]. On the point of Israel invading Palestine, I remember in school, in the history book that I read in Syria, it said that Jews were occupying Palestinian land, Canaan's land for a long period [...]. Jews were in that land, and Arabs took them out [...] and now they're coming and say that they have occupied our land” (Siwar, 26, Kurdish Atheist male from Qamishli, Syria).

Equating Israel with Nazism was often rejected by Kurds. They emphasized the completely different forms of discrimination or killings. Asked about his opinion on the statement "What the Nazis did to the Jews in World War II is the same as what Israel does to the Palestinians," Muhammed (22, Kurdish male from Kobane/Syria with Muslim but pro-PKK family background) responded by recounting a story about a chance encounter with Palestinian tourists from Jerusalem. They told him about their good life there but complained about the Israeli occupation. He replied to them that he had to flee to Germany and could not go back like they could and that he was not a tourist like them. Siyamend clearly recognizes that equating the Israeli Army and its actions with Jews in general is something he was taught in school.

"I know that there was this generalization, for example, if we saw the Israeli army doing bad things, we would think all Israelis are like this. And this is something they taught us at school, that every Israeli, every Jew is bad, because they were occupying a small part of Syria and such things. So by teaching you this while you are young, they promote [the idea] that Israelis are Jewish and are bad" (Siyamend, 22, Kurdish Muslim male from Qamishli, Syria). 
Kurds have been victims of discrimination in both Syria and Iraq. The nationalist Arab ideology and actions of the Baath Party were also aimed against them. These may be major reasons they reject the anti-Zionist-antisemitic part of the Arab nationalist ideology. At least under the regime of Hafez al-Assad, the daily oath of allegiance in the Syrian school system included an allegiance to the regime, to Arab unity, to the fight against the Muslim Brotherhood, and against Zionist imperialism. Even Kurdish school children were forced to swear this oath of Arab unity under threat of corporal punishment. Dila, 26, a Kurdish female from Syria, recounts:

"The real enemy for us students was not the Muslim brotherhood or Israel. Of course, they were talking about imperialism or Zionism, but when they were talking about that, they were also talking about the Kurds [...]. They were always connecting Kurds with imperialism, that they are getting support from imperialism, like imperial countries.”

For Kurds, perhaps this also made the propaganda against Zionist imperialism somewhat less convincing.

\section{Factors Influencing Antisemitic Positions}

The interviews pointed to six social or ideological factors of influence that can be expected to apply to other Syrian and Iraqi refugees. More research will need to be done to find out how powerful the individual factors are and whether others may exist.

(1) Among many of the participants, an antisemitic norm is prevalent in parts of the societies from which they come, as well as in their social environments. This is evident in antisemitic statements, which suggested the interviewees took some forms of antisemitism for granted. At the same time, participants spoke explicitly about a widespread hatred of Jews in their home countries. "I know that the majority of people don't like Jews in Iraq," said Abia (approximately in her mid-20s, Arab Muslim female from Bagdad/Iraq), while others hesitated to admit this.

(2) The governments in the participants' home countries engage in antisemitic propaganda, even including it in the official school curriculum. Interviewees from Syria in particular described a curriculum that declares Israel, but also Jews in general, as enemies. This is confirmed by studies on Syrian schoolbooks mentioned above. But even the uncritical study of certain works of world literature, like Shakespeare's Merchant of Venice-which is included in the literary canon for schools in Syria-can lead to or reinforce antisemitic stereotypes. 
(3) Antisemitism is widespread in old and new media and consumed uncritically. Participants explicitly mentioned books, television and the Internet, including YouTube, as sources of antisemitic notions. In new media in particular, conspiracy fantasies are spread quickly and are unfiltered, whether it is The Protocols of the Elders of Zion or conspiracy fantasies on the attacks of September 11, 2001, the Freemasons, the "Illuminati" or the Rothschild family, which all were mentioned by the interviewees.

(4) Some participants showed what could be termed "Palestine-ism," a notion that connects an identification with Palestinians to an automatic hatred of Israel and Jews. This type of over-identification with "the Palestinians" as victims does not allow for any differentiation and leads to an automatic hatred of Jews and Israel. It was prevalent among interviewees with a Palestinian background. Yanes, 32, an Arab-Palestinian Muslim male from Damascus, Syria, put it like this: "[A]s a Palestinian, I think both of them [Jews and Israelis] are my enemies."

(5) Fragments of a pan-Arab ideology, which include the cliche of the "Zionist imperialist" enemy, demonize Israel in a way that not only promotes notions of an Israeli-Jewish world conspiracy and aims at Israel's destruction, but also accuses Jews of sympathizing or working with a diabolical state. Arab nationalism can hardly be separated from a pan-Arab ideology, which relies on Israel as the enemy. It is also apparent in the notion of an imperialism led by Jews or Zionists targeting Syria or Iraq.

(6) Anti-Jewish, often Islamist interpretations of Islam declare "the Jews" to be the enemies of Muslims. Fragments of Islamist ideology and anti-Jewish interpretations of Islam can also be seen in non-Islamist Muslims. Some assumed a general hatred between "the Muslims" and "the Jews" and cited actual or alleged sources in Islam as proof.

These factors of influence often work together in arguments and in attitudes: they reinforce each other.

Günther Jikeli holds the Erna B. Rosenfeld Professorship at the Institute for the Study of Contemporary Antisemitism at Indiana University. His latest book (with Olaf Glockner) "The New Unease. Antisemitism in Germany Today" [in German] was published in 2019. In 2015, he published "European Muslim Antisemitism." with IU Press and "Perceptions of the Holocaust in Europe and Muslim Communities" (with Joelle Allouche-Benayoun) in 2013. His current research focuses on online antisemitism. 


\section{References}

Anti-Defamation League. “ADL GLOBAL 100.” Issued 2014. Accessed October 1, 2017. https:// global100.adl.org/.

Arnold, Sina, and Jana König. Flucht und Antisemitismus: Erste Hinweise zu Erscheinungsformen von Antisemitismus bei Geflüchteten und mögliche Umgangsstrategien: Qualitative Befragung von Expert_innen und Geflüchteten. Berlin: Berliner Institut für empirische Integrations- und Migrationsforschung (BIM), 2016. https:// www.bim.hu-berlin.de/media/Abschlussbericht_Flucht_und_Antisemitismus_SA_K.pdf.

Asquith, Christine. "A New History of Iraq." The Guardian, November 24, 2003. https://www. theguardian.com/education/2003/nov/25/schools.schoolsworldwide.

Berek, Mathias. Antisemitism and Immigration in Western Europe Today. Is there a connection? The case of Germany. Birkbeck: University of London, 2018.

Brücker, Herbert, Nina Rother, and Jürgen Schupp, eds. IAB-BAMF-SOEP-Befragung von Geflüchteten: Überblick und erste Ergebnisse. Nuremberg: Bundesamt für Migration und Flüchtlinge, 2016. http://www.forschungsnetzwerk.at/downloadpub/2016_fb29-iab-bamf_ soep-befragung-gefluechtete.pdf.

Bundesamt für Migration und Flüchtlinge. Aktuelle Zahlen zu Asyl. Nuremberg: Bundesamt für Migration und Flüchtlinge, 2017. https://www.bamf.de/SharedDocs/Anlagen/DE/Statis tik/AsylinZahlen/aktuelle-zahlen-zu-asyl-juli-2017.pdf?_blob=publicationFile\&v=5.

Bundesamt für Migration und Flüchtlinge. Das Bundesamt in Zahlen 2014: Asyl, Migration und Integration. Nuremberg: Bundesamt für Migration und Flüchtlinge, 2015. https:// www.bamf.de/SharedDocs/Anlagen/DE/Statistik/BundesamtinZahlen/bundesamt-in-zah len-2014.pdf?_blob=publicationFile\&v=14.

Bundesamt für Migration und Flüchtlinge. Das Bundesamt in Zahlen 2016: Asyl, Migration und Integration. Nuremberg: Bundesamt für Migration und Flüchtlinge, 2017. https:// www.bamf.de/SharedDocs/Anlagen/DE/Statistik/BundesamtinZahlen/bundesamt-in-zah len-2016.pdf?_blob=publicationFile \&v=16.

Bundeskriminalamt. Kriminalität im Kontext von Zuwanderung Bundeslagebild 2017. Issued May 8, 2018. https://www.bka.de/SharedDocs/Downloads/DE/Publikationen/Jahresber ichteUndLagebilder/KriminalitaetImKontextVonZuwanderung/KriminalitaetImKontextVon Zuwanderung_2017.pdf?_blob=publicationFile\&v=4.

Deutscher Bundestag. Bericht des Unabhängigen Expertenkreises Antisemitismus. Drucksache 18/11970. Issued April 7, 2017. https://dip21.bundestag.de/dip21/btd/18/119/1811970.pdf.

European Foundation for Democracy, ed. Refugees in Europe. Review of Integration Practices \& Policies. Brussels: European Foundation for Democracy, 2018. https://emnbelgium.be/ sites/default/files/publications/2018-Refugees-In-Europe-Full-Version.pdf.

Freytag, Ronald. Flüchtlinge 2016: Studie der HMKW zu Demokratieverständnis und Integrationsbereitschaft von Flüchtlingen 2016. Berlin: Hochschule für Medien, Kommunikation und Wirtschaft, 2016. https://www.hmkw.de/fileadmin/media/down loads/pdfs/Publikationen/HMKW_Fl\%C3\%BCchtlinge_2016_Studie_Ronald_Freytag_ 20160815.pdf.

Groiss, Arnon. Jews, Zionism and Israel in Syrian School Textbooks. Issued June 2001. Accessed October 1, 2017. http://www.impact-se.org/wp-content/uploads/2016/04/ Syria2001.pdf. 
Haug, Sonja, Edda Currle, Susanne Lochner, Dominik Huber, Amelie Altenbuchner.

Asylsuchende in Bayern: Eine quantitative und qualitative Studie. Abschlussbericht. Munich: Hanns-Seidel-Stiftung, 2017. https://www.hss.de/download/publications/Asylsu chende_in_Bayern.pdf.

Heugel, Renate. Die deutsch-arabische Freundschaft: Deutsche Geschichte (1815-1945) in syrischen Schulbüchern. Hamburg: Kovac, 2013.

Jikeli, Günther. Einstellungen von Geflüchteten aus Syrien und dem Irak zu Integration, Identität, Juden und Shoah: Forschungsbericht Dezember 2017. Berlin: American Jewish Committee, 2017. https://docplayer.org/68777670-Einstellungen-von-gefluechteten-aus-sy rien-und-dem-irak-zu-integration-identitaet-juden-und-shoah-forschungsbericht-dezem ber-2017.html.

Kamp, Melanie. "Vorurteile abbauen, Vielfalt schätzen: Ein Projekt für Geflüchtete.” In Discover Diversity: Politische Bildung mit Geflüchteten, edited by Aycan Demirel and Derviş Hızarcı, 32 - 37. Berlin: Kreuzberger Initiative gegen Antisemitismus, 2017. https:// www.vielfalt-mediathek.de/data/kiga_discover_diversity_vielfaltmediathek.pdf.

Kressel, Neil J. "The Sons of Pigs and Apes": Muslim Anti-Semitism and the Conspiracy of Silence. Dulles: Poto-mac Books, 2012.

Landis, Joshua M. Islamic Education in Syria: Undoing Secularism. Prepared for "Constructs of Inclusion and Exclusion: Religion and Identity Formation in Middle Eastern School Curricula," Watson Institute for International Studies, Brown University. Issued November 2003. Accessed October 1, 2017. https://pdfs.semanticscholar.org/be13/112be6d2 c4bee6f487dd988b2d40dcc12978.pdf.

Mut gegen rechte Gewalt. “Chronik flüchtlingsfeindlicher Vorfälle.” Accessed June 22, 2018. https://www.mut-gegen-rechte-gewalt.de/service/chronik-vorfaelle.

Nettler, Ronald L. Past Trials and Present Tribulations: A Muslim Fundamentalist's View of the Jews. Oxford: Pergamon, 1987.

Pew Research Center. Little Enthusiasm for Many Muslim Leaders: Mixed Views of Hamas and Hezbollah in Largely Muslim Nations. Washington: Pew Research Center, 2010. https:// www. pewresearch.org/wp-content/uploads/sites/2/pdf/268.pdf.

Statistisches Bundesamt. "Zahlen für 2016." Issued 2017. Accessed September 1, 2017. https://www.destatis.de/DE/ZahlenFakten/GesellschaftStaat/Bevoelkerung/MigrationInte gration/MigrationIntegration.html.

Tibi, Bassam. Islamische Zuwanderung und ihre Folgen-Wer sind die neuen Deutschen? Hannover: ibidem-Verlag, 2017.

Zick, Andreas, Andreas Hövermann, Silke Jensen, and Julia Bernstein. Jüdische Perspektiven auf Antisemitismus in Deutschland. Ein Studienbericht für den Expertenrat Antisemitismus. Bielefeld: Institut für interdisziplinäre Konflikt- und Gewaltforschung, Universität Bielefeld, 2017. https://uni-bielefeld.de/ikg/daten/JuPe_Bericht_April2017.pdf. 